DOI https://doi.org/10.18551/rjoas.2018-03.17

\title{
ANALYZING THE ADAPTIVE CAPACITY TO CLIMATE CHANGE OF THE RICE FARMERS: A CASE STUDY OF PASURUAN REGENCY, EAST JAVA, INDONESIA
}

\author{
Salampessy Yudi L.A.* \\ Agriculture Faculty, Sultan Ageng Tirtayasa University, Banten, Indonesia \\ Lubis Djuara $\mathbf{P}$. \\ Human Ecology Faculty, Bogor Agricultural University, Bogor, Indonesia \\ Amien Le Istiqlal \\ Agro-climatology and Hydrology Research Institute, Bogor, Indonesia \\ Suharjito Didik \\ Forestry Faculty, Bogor Agricultural University, Bogor, Indonesia \\ *E-mail: ysalampessy@gmail.com
}

\begin{abstract}
As the seasonal crops, rice production is very dependent on the climate carrying capacity, so the changing climate requires the ability of the farmers to adapt. On the other hand, climate change is still a new and complex issue for most people, followed by differences in response to its impact. This study explores the adaptive capacity to climate change of the rice farmers. Survey method applied in rice cultivation area affected by climate change involving 96 rice farmers as respondents. The result shows that rice farmers are less adaptive to climate change, especially those in highland agroecosystem zones. It requires a flow of information and the availability of climate change adaptation support components to the farmers' side, as well as studies that can extract the determinants of adaptive capacity to climate change of the farmers.
\end{abstract}

\section{KEY WORDS}

Adaptation, agroecosystem zone, climate change, information, rice farmers.

Climate change has occurred in Indonesia. The temperature has been rising for decades and is expected to continue to increase until 2020 and there are indications of the rising sea levels up to 2100 (IPCC, 2007) that could cause coastal lowland areas such as Surabaya to have a higher risk of flood (PEACE, 2007). In addition, there have been changes in the rainy and dry seasons. Rainfall in the rainy season in southern Indonesia increased, while rainfall in the dry season in the northern region has increased. (Boer and Faqih, 2004; Naylor et al., 2007).

As the seasonal crops, the success of rice field production is highly dependent on the climate carrying capacity. Generally, farmers rely on instinct or habit in the application of cropping pattern that refers to pranotomongso, a kind of dating of the Javanese community related to planting activities. Climate change shifts those provisions due to reduced water discharge from water sources, prolonged rainy or dry seasons, and extreme weather, followed by the decrease in rice production. The impact of climate change in Indonesia, is predicted by Handoko et al. (2008), will lead to the decrease in rice production by 10,473,764 tons in 2050 or $20.3 \%$ of production in 2006 of $51,647,490$ tons, while in East Java, is predicted by Amien et al. (1996), will decrease by about $1 \%$ per year. In Pasuruan itself, rice productivity has decreased by $0.21 \%$ due to climate anomalies and brown planthopper pest attack (Maria, 2017).

These real conditions and estimation confirm that the sustainability of rice farming and local food security requires farmers' ability to adapt to climate change. On the other hand, climate change is still a new and complex issue for most people, followed by differences in 
responses to local impacts (Asplund, 2014; Buys et al., 2011; Wibeck, 2014). This article aims to describe the adaptive capacity to climate change of the rice farmers in the lowland, medium and highland agroecosystem zones.

\section{METHODS OF RESEARCH}

The study is designed as survey study. The study location was chosen purposively in Gempol, Purwosari and Prigen Sub-districts of Pasuruan, East Java, because of its lowland, medium, and highland agroecosystems are affected by climate change. The amount of sample is set at 96 farmers consisting of 32 farmers from each sub-district drawn by simple random technique proportionally. Data were collected by questionnaire instrument.

The adaptive capacity to climate change of the respondents is measured through composite scores (means) of all questions (Budiaji, 2013) on indicators of knowledge level, attitude, skill level and application of climate change adaptation. Data were analyzed descriptively through single table and test of difference of the mean value of t-test.

Table 1 - Score and category of respondent value attainment in each indicator

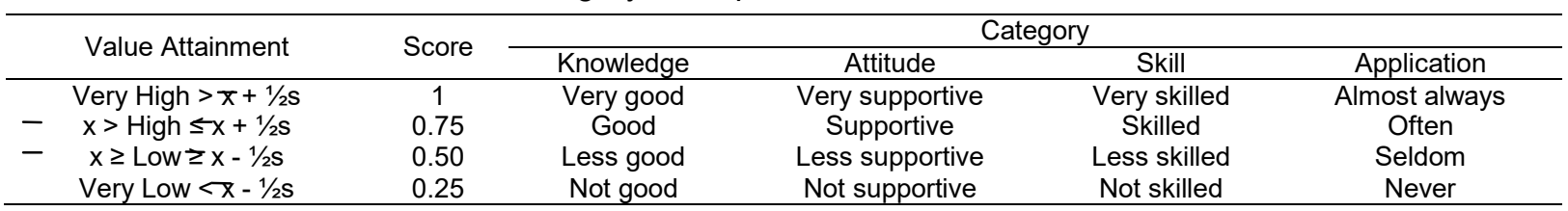

Source: Modified from Nakuja et al. (2012); Mabe et al. (2012).

Note: $x=$ mean of respondent value attainment in each indicator; $s=$ deviation standard of respondent value attainment in each indicator.

Table 2 - Distribution of adaptive capacity to climate change of the respondents

\begin{tabular}{ccc}
\hline Adaptive Capacity (AC) & \multicolumn{2}{c}{ Score Range } \\
\cline { 2 - 3 } & Distribution (D) & Mean (M) \\
\hline Not adaptive & DAC $\leq 0.50$ & MAC $\leq 0.50$ \\
Less adaptive & $51 \leq$ DAC $\leq 0.75$ & $51 \leq$ MAC $\leq 0.75$ \\
Adaptive & DAC $>0.75$ & MAC $>0.75$ \\
\hline
\end{tabular}

\section{RESULTS AND DISCUSSION}

Adaptive Capacity to Climate Change of the Respondents. The result of the analysis shows that most respondents are still less able to adapt to climate change as seen in Figure 1. The adaptive capacity scores presented in Table 3 also shows that, in general, and in every indicator, respondents are still less adaptive to climate change.

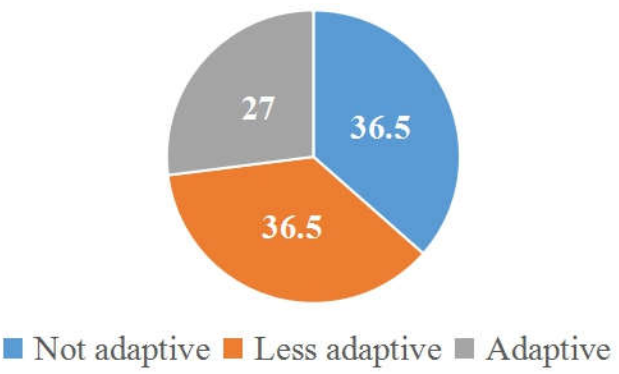

Figure 1 - Distribution of respondents based on adaptive capacity to climate change, $\%$

Table 3 - Adaptive capacity to climate change of the respondents

\begin{tabular}{ccc}
\hline Adaptive Capacity to Climate Change & Score & Category \\
\hline Knowledge of climate change adaptation & 0.66 & Less adaptive \\
Attitudes to climate change adaptation & 0.61 & Less adaptive \\
Skills of climate change adaptation & 0.57 & Less adaptive \\
Application of climate change adaptation & 0.62 & Less adaptive \\
\hline Average & 0.62 & Less adaptive \\
\hline
\end{tabular}


The less adaptive knowledge of climate change adaptation is shown by the knowledge scores of respondents in Table 4. This condition occurred because most of the respondents still do not know the name and specification of rice varieties that are tolerant to immersion, drought, and pest attack. Almost all respondents still plant rice varieties such as IR64, Ciherang, and Way Apo Buru which are already vulnerable to the climate change effects. Knowledge of cropping pattern is also less adaptive because there are still many respondents who less aware of the existence and importance of climate information for the management of rice farming, so they often confused in defining the current season and determine the beginning and planting commodity.

Table 4 - Level of knowledge of climate change adaptation of the respondents

\begin{tabular}{ccc}
\hline Knowledge of Climate Change Adaptation & Score & Category \\
\hline Water management & 0.75 & Less adaptive \\
Application of cropping pattern according to the climate conditions & 0.72 & Less adaptive \\
Utilization of climate-change-tolerant rice varieties & 0.52 & Less adaptive \\
\hline Average & 0.66 & Less adaptive \\
\hline
\end{tabular}

Despite having the highest score, the knowledge of water management of respondents to overcome the water stress is still less adaptive. There are still some respondents who are less aware of water storage technology. Pasuruan has long been known as a district with many sources of water so that respondents are not getting used to storing water to overcome the lack of water due to population and industry growth or unpredictable weather. They prefer to request irrigation water from nearby districts although the supply may not necessarily meet the needs.

Attitudes to climate change adaptation are still less adaptive, primarily to the effects of climate change as shown in Table 5. Many respondents think that the climate is determined by God and cannot be changed by humans. Respondents' attitudes are also heavily based on the assessment of cost advantages of climate change adaptation strategy application. For many respondents, resting the land means lost income. In locations where the water is available throughout the year, rotating the cropping commodities is considered to be detrimental because rice is more needed, although it is a powerful strategy to restore soil nutrients and break the life cycle of pests. On the other hand, most respondents are adaptive to the paddy cultivation technology that is in line with some climate change adaptation strategies such as simultaneous planting, use of organic materials, and adjustment of agricultural practice with the weather conditions. Thus, respondents are more scientific about the technology of rice cultivation that they may apply but tend to be fatalistic to the climate problems.

Table 5 - Level of attitudes to climate change adaptation of the respondents

\begin{tabular}{ccc}
\hline Attitudes to Climate Change Adaptation & Score & Category \\
\hline Climate change & 0.67 & Less adaptive \\
Climate change adaptation strategy & 0.63 & Less adaptive \\
Climate change impact & 0.53 & Less adaptive \\
\hline Average & 0.61 & Less adaptive
\end{tabular}

Skills of climate change adaptation on Table 6 shows that the skills of respondents are less adaptive on climate change. This is because job training outside the agricultural sector is still rare. For the instructors themselves, such training would be useless because most farmers would still farm in any climatic conditions considering only that it is owned and can be done. In addition, the instructors did not have those duties and skills.

Similar conditions occurred in the rice management skills in uncertain weather. Most respondents are more often trained in pest control while training such as the use of planting calendars and planting rice varieties that are tolerant to climate change is almost never found. Pest control skills obtained by respondents through Integrated Pest Control Field School that are held well-scheduled in the houses or fields of the farmer group. This approach is quite successful in improving the skills of respondents in pest control. 
Table 6 - Level of skills of climate change adaptation of the respondents

\begin{tabular}{ccc}
\hline Skills of Climate Change Adaptation & Score & Category \\
\hline Water management & 0.62 & Less adaptive \\
Plant management skills in uncertain weather & 0.58 & Less adaptive \\
Working outside the agricultural sector & 0.52 & Less adaptive \\
\hline Average & 0.57 & Less adaptive \\
\hline
\end{tabular}

Water management skills of the respondents are also less adaptive to the climate change, although these skills are usually inherent in farmers because they have been taught for generations. For example, respondents in the lowlands reduce the irrigation water absorption into the soil by utilizing a barrel to coat the water line and control the excess water flow through open the floodgates. Farmers in the highlands distribute the water to all fields through pipelines and irrigation time splits. However, this study measures the skills of respondents from the frequency of respondents getting training in water management technology. This is because climate change demands more diverse water management skills, such as water storage technology as well as water drilling and suction to anticipate the decrease of water discharge from water sources, uncertain seasons, and extreme weather. In fact, the respondents are very rarely getting such training.

Application of climate change adaptation is not yet fully adaptive to the climate change in terms of job diversification as it appears in Table 7. Most of the respondents still make rice farming as the main source of income, even though farming is difficult to do. Soil management is also less adaptive because most respondents only observe the dryness of the rice fields, but almost never rest the land even though it can increase the nutrients and break the life cycle of the pest.

Table 7 - Level of application of climate change adaptation of the respondents

\begin{tabular}{ccc}
\hline Application of Climate Change Adaptation & Score & Category \\
\hline Plant management & 0.60 & Less adaptive \\
Soil management & 0.62 & Less adaptive \\
Water management & 0.66 & Less adaptive \\
Job diversification & 0.54 & Less adaptive \\
\hline Average & 0.61 & Less adaptive \\
\hline
\end{tabular}

Although most respondents always maintain the water channels and use the water effectively and efficiently, the respondent's water management has not yet applied water storage and pumpinization technology because of cost consideration and geographical conditions. Some adaptation strategies for climate change are difficult for respondents to use, such as drilling wells during highland drought. In the medium-land, not all places are easy to drill because its underlying rocky layer and drilling permits are relatively difficult to obtain. The cost of groundwater drilling becomes expensive and adds to the high cost of rice field farming. In contrast, lowland respondents who are often sunken by the flood cannot use water pumps to reduce flooding due to the low geographical location and the existence of silting of the river due to Lapindo mudflow, so that rainwater and runoff water through the area cannot flow fast.

Most of the planting management of the respondents are also less adaptive because it tends to be conventional, such as planting simultaneously and monitoring plant growth. Meanwhile, planting climate-change-tolerant rice varieties, utilizing climate information, crop rotation, use of organic materials, and pest traps are still rare. This indicates that the adaptation activities undertaken by the respondents have been more revolved around the rice cultivation technology commonly used for generations in the management of the farming system, which is also incidentally in line with some adaptation strategies to climate change developed scientifically today.

Differences in Adaptive Capacity to Climate Change. Completing the description above, the adaptive capacity to climate change is further differentiated by agroecosystem zone. The test result of One Way Anova $F_{2,93}=4.33$ at probability value 0.01 shows the difference of mean score of adaptive capacity to climate change of the farmers in all three agroecosystem zones. Table 8 shows the highest average adaptive capacity to climate change of the farmers 
in medium-agroecosystem zones, followed by farmers in lowland agroecosystem zones, and farmers in highland agroecosystem zones. The average adaptive capacity to climate change of the respondents that is significantly different is the adaptive capacity to climate change of the respondents in highland agroecosystem zone, while for medium and lowland are not significantly different.

Table 8 - Differences of adaptive capacity to climate change between agroecosystem zones Tukey HSD

\begin{tabular}{|c|c|c|c|}
\hline \multirow{2}{*}{ Agroecosystem Zone } & \multirow{2}{*}{$\mathrm{N}$} & \multicolumn{2}{|c|}{ Subset for alpha $=0.05$} \\
\hline & & 1 & 2 \\
\hline Prigen Subdistrict & 32 & .5443 & \\
\hline Gempol Subdistrict & 32 & & .6504 \\
\hline Purwosari Subdistrict & 32 & & .6556 \\
\hline Sig. & & 1.000 & .992 \\
\hline
\end{tabular}

Means for groups in homogeneous subsets are displayed.

Basically, farmers will always instinctively adjust the management of rice farming with climatic conditions, because as the seasonal crops, rice is very dependent on the natural environment so it is more vulnerable to various risks (Kimura et al., 2009). On the other hand, climate change is a global phenomenon that still becomes a new and complex issue to be understood for most people, so that its local impacts will be responded to the social, economic, and agricultural system characteristics of the rice farmers. Previous studies also explain that farmers have a fatalistic tendency toward the climate change (Dayour et al., 2014; Cherif and Greenberg, 2013; Charles and Johann 2016; Akanda and Howlader, 2015). This condition affirms Rambo's statement (1985) that in addition to the few real things about the ecosystem that rural people understand, the conceptualization of the ecosystem also includes aspects that are now unbelievable. Thus, capacity building for climate change adaptation requires a flow of climate change information and communication from the experts to the farmers.

The lack of climate change adaptation skills of the respondents confirms that training and the experts' availability shortages may limit the ability of households, communities, or nations to implement adaptation options (Asante et al., 2012). Thus, adaptation training for the farmers is needed. Communications approaches such as in pest control training are still relevant enough to be used because a place-based approach to discuss climate change impacts on specific areas, communities and locations promise more effective message delivery (Grossman, 2005; Thompson and Schweizer, 2008).

The application of climate change adaptation of respondents shows reactive adaptation measures, i.e. adaptations are implemented after the impacts of climate change have been perceived (Dolan et al., 2001). This is a logical consequence of the level of knowledge, attitudes, and adaptation skills of the respondents, as the explanation of Lorenzoni et al. (2007) that the level of farmer involvement in climate change is related to basic knowledge, values, experience, and lifestyle and all of that is influenced by the breadth of the social level. Therefore, knowledge about climate needs to be seriously communicated to ensure the agribusiness sector recognizes the value of the effective adaptation to the risk of uncertain climate (Moser, 2010; Nisbet, 2009), which can instill positive understanding and attitudes toward the environment, citizen action competence, and in the sense of empowerment (Monroe et al., 2000).

Differences in adaptive capacity to climate change of the respondents emphasized the importance of considering the suitability of adaptation strategies built or offered with the location and geographical conditions of rice farming. Some adaptation technologies may have to be sought for the substitution as they are quite difficult to be applied by the farmers in the highlands. In addition, the adaptation strategy support component should also be considered its availability to be easily accessible to them. This refers to the statement of Penalba et al. 
(2012) that the awareness of climate change and its impact may not be transformed into actions for social and economic reasons.

This description of adaptive capacity to climate change is important because it not only explains the known and unknown climate change adaptation strategies but also how their attitudes, skills, and actions respond to the climate stimuli. Such information not only can open the minds of the government to the knowledge of the environment already possessed by the villagers that can complement the current knowledge of the scientists (Rambo, 1985), but also can be an input or evaluation of the suitability of climate change adaptation strategy implemented by the stakeholders.

\section{CONCLUSION AND SUGGESTIONS}

Rice farmers are less adaptive to the climate change, especially those in highland agroecosystem zones. It can be shown from the lack of knowledge and skills of specific issues related to the climate change, the attitude that tends to be fatalistic to the climate problems, as well as adaptation actions that tend to be reactive rather than anticipatory in responding to the climate change as a global phenomenon that impacts locally. This requires the flow of information through a variety of communication channels including the climate change adaptation training for farmers, as well as government policies that are able to encourage the availability of supporting components of climate change adaptation to the farmers. The implementation of both should refer to the results of the studies that extracts the determinant factors of adaptive capacity to climate change of the farmers including how the experience and what the farmers understand about the visible climate change manifestation.

\section{REFERENCES}

1. Akanda, M.G.R., and Howlader, M.S. (2015). Coastal farmers' perception of climate change effects on agriculture at Galachipa Upazila under Patuakhali District of Bangladesh. Glob J Sci Frontier Research: D Agriculture and Veterinary, 15(4):31-39.

2. Amien, I., Rejekiningrum, P., Pramudia, A., and Susanti, E. (1996). Effects of interannual climate variability and climate change on rice yield in Java, Indonesia. Di dalam: Erda, L., Bolhofer, W.C., Huq, S., Lenhart, S., Mukherjee, S.K., Smith, J.B., and Wisniewski, J (Eds). Climate Change Vulnerability and Adaptation in Asia and the Pacific: 15-19 January 1996, Manila, Philippines. SPRINGER, pp 29-39.doi: 10.1007/978-94-017-1053-4.

3. Asante, F.A., Boakye, A.A., Egyir, I.S., and Jatoe, J.B.D. (2009). Climate change and farmers' adaptive capacity to strategic innovations: the case of northern Ghana. Int J Development and Sustain. 1(3):766-784

4. Asplund, T. (2014). Natural versus anthropogenic climate change: Swedish farmers' joint construction of climate perceptions. PUS. 25(5):560-75.doi: 10.1177/0963 6625145 59655

5. Boer, R., and Faqih, A. (2004). Global climate forcing factors and rainfall variability in west java: Case study in Bandung district. Indonesian J Agriculture Meteorology. 18(2):11-28.

6. Budiaji, W. (2013). Skala pengukuran dan jumlah respon Skala Likert. Jurnal IImu Pertanian dan Perikanan. 2(2):127-133

7. Buys, L., Miller, E., and Megen, V.K. (2011). Conceptualising climate change in rural Australia: Community perceptions, attitudes and (in) actions. Reg Environ Change. 12(1):237-248.doi: 10.1007/s10113-011-0253-6

8. Charles, G., and Johann, G. (2016). From climate perception to action: Strategic adaptation for small island farming communities a focus on Malta. Watch Letter n³7.https://ciheam.org/uploads/attachments/265/021_Galdies_WL_37.pdf

9. Cherif, S., and Greenberg, J.H. (2013). Religious perspectives on climate change in the West Ivoirian Mountainous region. Di dalam: Veldman RG, Szasz A, (Ed.), Haluza-DeLay $\mathrm{R}$, (Ed.). How the World's Religions are Responding to Climate Change. Routledge, London, pp 126-138 
10. Dayour, F., Yendaw, E., and Jasaw, G.S. (2014). Local residents' perception and adaptation/ coping strategies to climate-induced disasters in Bankpama, Wa West District, Ghana. Int J Dev Sustain. 3(12):2186-2205.

11. Maria, Eka. (2017). Potensi pertanian padi. http://pasuruankab.go.id/potensi-122-padi-.html

12. Dolan, A.H., Smit, B., Skinner, M.W., Bradshaw, B., and Bryant, C.R. (2001). Adaptation to Climate Change in Agriculture: Evaluation of Options. Occasional Paper No. 26. Department of Geography, University of Guelph.

13. Grossman, D. (2005). Observing those who observe. Nieman Reports. 59(4):80-85.

14. Handoko, I., Sugiarto, Y., dan Syaukat, Y. (2008). Keterkaitan Perubahan Iklim dan Produksi Pangan Strategis: Telaah Kebijakan Independen dalam Bidang Perdagangan dan Pembangunan. SEAMEO BIOTROP, Bogor, Indonesia.

15. IPCC. (2007). Climate Change 2007: Synthesis Report. Contribution of Working Groups I, II and III to the Fourth Assessment Report of the Intergovernmental Panel on Climate Change. IPCC. Geneva, Swiss

16. Kimura, S., Anton, J., and Lethi, C. (2009). Managing Risk in Agriculture: a Holistic Approach. OECD. Paris, France

17. Lorenzoni, I., Cole, N.S., and Whitmarsh, L. (2007). Barriers perceived to engaging with climate change among the UK public and their policy implications. J GLOENVCHA. 17:445-459.doi:10.1016/j.gloenvcha.2007.01.004.

18. Mabe, F.N., Sarpong, D.B., and Osei-Asare, Y. (2012). Adaptive capacities of farmers to climate change adaptation strategies and their effects on rice production in the northern region of Ghana. Russian Journal of Agricultural and Socio-Economic Sciences. 11(11):9-17

19. Monroe, M.C., Day, B.A., and Grieser, M. (2000). GreenCOM Weaves Four Strands dalam Environmental Education \& Communication for a Sustainable World: Handbook for International Practitioners (Brian A. Day and Martha C. Monroe, Editors). Academy for Educational Development. USA

20. Moser, S.C. (2010). Communicating climate change: history, challenges, process and future directions. Wires Clim Change. 1:31-53.doi: 10.1002/wcc.011.

21. Nakuja, T., Sarpong, D.B., Kuwornu, J.K.M., and Asante, A.F. (2011). Water storage for dry season vegetable farming as an adaptation to climate change in the upper east region of Ghana. AJAR. 7(2):298-306.doi:10.5897/AJAR11.1601.

22. Naylor, R.L., Battisti, D.S., Vimont, D.J., Falcon, W.P., and Burke, M.B. (2007). Assesing the risk of climate variability and climate change for Indonesian rice agriculture. Di dalam: Schekman R, editor. Proceedings of the National Academy of Sciences of the United States of America; 2007 May 8, Washington DC: National Academy of Sciences. 104(19):7752-7757.doi:10.1073/pnas.0701825104.

23. Nisbet, M. (2009). Communicating climate change: Why frames matter for public engagement. Environment: Science and Policy for Sustainable Development. 51(2): 12-23.http://dx.doi.org/10.3200/ENVT.51.2.12-23

24. PEACE. (2007). Indonesia and Climate Charge: Current Status and Policies. PEACE. Jakarta, Indonesia.

25. Penalba, L.M., Elazegui, D.D., Pulhin, J.M., and Cruz, R.V.O. (2012). Social and institutional dimensions of climate change adaptation. Int J Climate Change Strategies and Management. 4(3):308-322.doi:10.1108/17568691211248748

26. Rambo, A.T. (1985). Information Flow in Ecological Systems: a Theoretical Basis for the Study of Environmental Communication. In KLH-EWC-AMIC Workshop on 'Environmental Communication': Apr 1-3, 1985, Singapore. Asian Mass Communication Research and Information Centre. Nanyang Technological University Library.

27. Thompson, J.L., and Schweizer, S.E. (2008). The conventions of climate change communication. Paper presented at the National Communication Association Convention: November 20-24, 2008, San Diego. California, USA

28. Wibeck, V. (2014). Social representations of climate change in Swedish lay focus groups: Local or distant, gradual or catastrophic? 23(2):204-19.doi:10.1177/0963662512462787. 